\title{
Ephrin Type-A Receptor 2
}

National Cancer Institute

\section{Source}

National Cancer Institute. Ephrin Type-A Receptor 2. NCI Thesaurus. Code C26156.

Ephrin type-A receptor 2 (976 aa, $108 \mathrm{kDa}$ ) is encoded by the human EPHA2 gene. This protein plays a role in ephrin-A binding, cell-cell signaling and signaling pathway regulation. 